\title{
IDENTIFIKASI PENCEMARAN LOGAM BERAT RAKSA DI SUNGAI CITARUM HULU JAWA BARAT
}

\author{
Eka Wardhani \\ Jurusan Teknik Lingkungan, Institut Teknologi Nasional \\ Jalan PHH. Mustofa 23 Bandung 40124 \\ Email : eka_wardhani@yahoo.com
}

\begin{abstract}
Abstrak
Sungai Citarum Hulu telah mengalami degradasi kualitas sampai kondisi kritis, sepanjang 12 $\mathrm{km}$ atau $47,1 \%$ telah tercemar berat oleh air limbah yang berasal dari aktivitas industri, domestik, dan pertanian. Penelitian ini bertujuan untuk mengetahui kandungan logam berat Raksa (Hg) di Sungai Citrum Hulu dan mengevaluasi dampak yang akan terjadi. Hasil penelitian menunjukkan kandungan logam berat Hg di Sungai Citarum Hulu adalah 0,0032 $\mathrm{mg} / \mathrm{L}$ untuk Citarum Wangisagara, 0,0042 mg/L untuk Citarum Sapan, 0,0002 mg/L untuk Citarum Dayeuhkolot, 0,008 mg/L untuk Citarum Nanjung dan 0,0043 mg/L untuk Citarum Tanjungpura. Semuanya masih berada di bawah baku mutu yaitu $0,01 \mathrm{mg} / \mathrm{L}$, tetapi ada dua anak sungai Citarum Hulu yaitu Sungai Citepus Cisirung 0,0228 mg/L dan Sungai Cimahi Leuwigajah 0,0183 mg/L yang kandungan raksanya sudah melewati baku mutu. Hasil penelitian ini diharapkan dapat memberikan informasi mengenai kondisi perairan yang sebenarnya mengingat fungsi dari Sungai Citarum Hulu yang sangat penting, salah satunya merupakan sumber air utama yang mengairi tiga waduk besar yaitu Saguling, Cirata, dan Jatiluhur yang oleh masyarakat sekitar dimanfaatkan sebagai areal budidaya perikanan jaring terapung dan sumber irigasi bagi pertanian di daerah Jawa Barat.
\end{abstract}

Kata kunci : Citarum, raksa, pH, oksigen terlarut

\begin{abstract}
The Citarum Hulu river has undergone degradation in its water quality to a critical condition, in which $12 \mathrm{~km}$ or $47.1 \%$ of the river being heavily polluted by wastewater originating from industrial, domestic, and agricultural activities. This research was aimed at determining the mercury ( $\mathrm{Hg}$ ) metal content of Citarum Hulu river, and to evaluate the impacts that are likely to occur. Research results obtained in the Citarum Hulu area indicated an $\mathrm{Hg}$ heavy metal content of $0.0032 \mathrm{mg} / \mathrm{L}$ in Citarum Wangisagara, $0.0042 \mathrm{mg} / \mathrm{L}$ in Citarum Sapan, 0.0002 $\mathrm{mg} / \mathrm{L}$ in Citarum Dayeuhkolot, $0.008 \mathrm{mg} / \mathrm{L}$ in Citarum Nanjung, and $0.0043 \mathrm{mg} / \mathrm{L}$ in Citarum Tanjungpura tributaries. These are all still below the standard limit of $0.01 \mathrm{mg} / \mathrm{L}$. However, two tributaries indicated higher than standard Hg content, namely $0.0228 \mathrm{mg} / \mathrm{L}$ in Citepus Cisirung and $0.0183 \mathrm{mg} / \mathrm{L}$ in Cimahi Leuwigajah tributaries. Results from this research were expected to provide information on the actual water condition, considering the key role of Citarum Hulu river as the main source of water supply for three major dams in West Java, namely Saguling, Cirata, Jatiluhur dams. These dams are utilized by the local population for floating net fishery and for the irrigation of local agricultural farms.
\end{abstract}

Kata kunci : Citarum river, mercury, pH, dissolved oxygen 


\section{Pendahuluan}

Perkembangan industri di Kota Bandung dan sekitarnya memungkinkan semakin banyaknya limbah industri yang dibuang ke badan air, dalam hal ini sungai. Pada tahun 2001 di wilayah ini terdapat sekitar 400 buah industri yang $74,5 \%$ diantaranya merupakan industri tekstil dan lainnya merupakan aneka industri, industri logam dan mesin, kimia, makanan-minuman dan farmasi. Selain aktivitas industri aktivitas lain yang membuang limbah ke sungai adalah aktivitas domestik, pertanian dan perhotelan (Prokasih, 2003 dan BPLHD Jawa Barat, 2003). Dari beberapa aktivitas tersebut ada yang menghasilkan limbah berupa logam berat yang menurut penelitian menunjukkan bahwa industri tekstil, besi/baja, farmasi, kertas dalam proses produksinya banyak menghasilkan logam berat seperti raksa, cadmium, krom, seng dan lain-lain (Prokasih, 2003 dan BPLHD Jawa Barat, 2003). Salah satu aliran sungai di wilayah Jawa Barat yaitu Sungai Citarum Hulu, dimana sungai ini merupakan salah satu aliran utama dimana limbah dari kegiatan industri dan aktivitasaktivitas lainnya dibuang.

Kualitas air Sungai Citarum Hulu saat ini sangat menghawatirkan karena terjadi pencemaran yang sangat berat terutama di bagian hulu, setiap harinya diperkirakan 280 ton limbah masuk ke sungai ini (Republika, 2002). Kandungan beberapa logam berat juga sudah melewati ambang batas yang telah ditetapkan. Meskipun diketahui bahwa keberadaan logam berat di perairan merupakan hal yang alamiah terbatas dalam jumlah tertentu yang ada dalam kolom air, sedimen dan lemak biota, namun keberadaan logam berat ini akan meningkat akibat masuknya limbah yang dihasilkan oleh industri-industri, dan juga limbah yang berasal dari aktivitas lainnya.

Dalam proses biologi, logam berat merupakan zat yang esensial artinya dibutuhkan dalam jumlah sedikit, namun bila zat tersebut terdapat dalam jumlah yang berlebihan dapat menimbulkan keracunan. Efek ini diperkuat karena logam-logam ini dapat berakumulasi dalam tubuh organisme perairan yang nantinya dapat masuk ke rantai makanan dan akhirnya terakumulasi pada tubuh manusia (Goldberg, 1983).

Dalam usaha untuk mengendalikan pencemaran air sungai khususnya dari pencemaran logam berat yang bersifat resisten di alam dan beberapa diantaranya bersifat toksik, diperlukan studi yang dapat dipergunakan untuk menganalisis pola perilaku penyebaran kontaminan dalam air dan sedimen sungai.

Tujuan dari penelitian ini adalah mengetahui kondisi perairan terutama kandungan logam berat Raksa dalam air Sungai Citarum Hulu. Ruang lingkup penelitian ini adalah menganalisis sampel air di 5 titik di Sungai Citarum Hulu dan 13 titik yang berasal dari anak Sungai Citarum Hulu. Pengambilan sampel dilakukan pada bulan April 2006 mewakili musim hujan dan bulan Agustus 2006 mewakili musim kemarau, untuk anak Sungai Citarum Hulu dilakukan juga pada bulan November 2006 mewakili musim kemarau. Analisis untuk parameter pendukung dilakukan untuk daya hantar listrik (DHL), suhu, oksigen terlarut (dissolved oxygen, DO), dan $\mathrm{pH}$. Dari hasil penelitian ini diharapkan dapat memberi informasi pada masyarakat dan Pemerintah Daerah akan kondisi Sungai Citarum Hulu yang sebenarnya.

\section{Metodologi}

Penelitian ini diawali dengan studi pustaka serta pengumpulan data sekunder yang dapat menunjang penelitian, dilanjutkan dengan pengambilan sampel di lapangan dan analisis laboratorium. Logam berat Raksa (Hg) dianalisis di laboratorium dengan menggunakan metoda Atomic Absorption Spectrofotometer (AAS) sedangkan parameter pendukung langsung dianalisis di lapangan seperti DHL, suhu, $\mathrm{pH}$, dan oksigen terlarut (DO). Semua parameter dianalisis sesuai dengan Standar Nasional Indonesia (SNI), metode analisis selengkapnya dapat dilihat pada Tabel 1.

Tabel 1. Metode Analisis Kualitas Air

\begin{tabular}{|c|c|c|}
\hline No & Parameter & Metode Analisis \\
\hline 1 & $\begin{array}{l}\text { Metode sampling } \\
\text { kualitas air }\end{array}$ & SK SNI-M-02-1989-F \\
\hline 2 & $\begin{array}{l}\text { Dava hantar } \\
\text { listrik (DHL) }\end{array}$ & SK SM-M-03-1989-F \\
\hline 3 & Suhu & SK SNI-M-03-1989-F \\
\hline 4 & $\mathrm{pH}$ & SK SNI-M-03-1989-F \\
\hline 5 & $\begin{array}{l}\text { Oksigen terlarut } \\
\text { (DO) }\end{array}$ & SK SM-M-03-1989-F \\
\hline 6 & Raksa & $\begin{array}{l}\text { SK SM-M-31-1990- } \\
03\end{array}$ \\
\hline
\end{tabular}


Pelaksanaan kegiatan analisis laboratorium kualitas air dilakukan di laboratorium Kimia Fisika Universitas Padjajaran di Jalan Raya Sumedang km 21, Jatinangor. Bagan alir penelitian dapat dilihat pada Gambar 1.

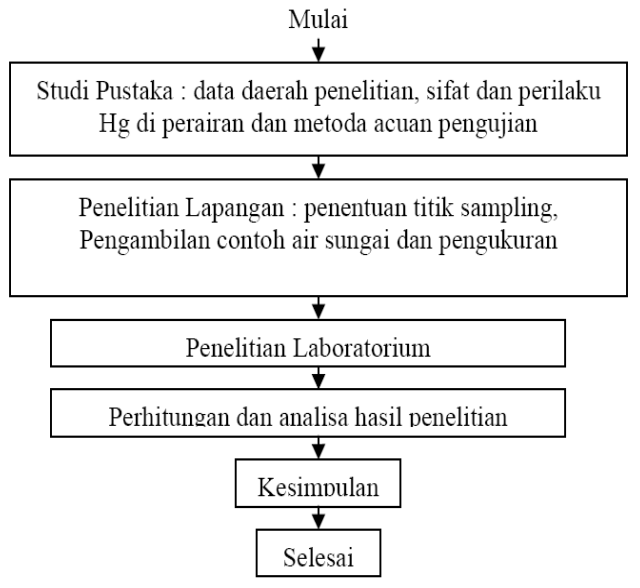

Gambar 1. Bagan Alir Penelitian

\section{Hasil dan Pembahasan}

Pengambilan sampel air dilakukan di Sungai Citarum dan anak sungainya Pengambilan sampel di Sungai Citarum dilakukan dua kali yaitu bulan April yang mewakili musin hujan dan bulan Agustus mewakili musim kemarau. Lokasi pengambilan sampel air dilakukan di 5 titik yaitu CTR-1 = Citarum Hulu Wangisagara, CTR-2 = Citarum Hulu Sapan, CTR-3 = Citarum Hulu Dayeuhkolot, CTR-4 = Citarum Hulu Nanjung, CTR-5 = Citarum Hulu Tanjungpura. Selain itu untuk melengkapi penelitian dilakukan pengambilan sampel di anak sungai Citarum yang dilakukan tiga kali pengambilan yaitu bulan April, Agustus dan November yang mewakili musim hujan dan kemarau dengan jumlah anak sungai yang diambil sebanyak 13 buah. Data selengkapnya dapat dilihat pada Tabel 2. Data hasil pengamatan parameter kualitas air Sungai Citarum Hulu selengkapnya dapat dilihat pada Tabel 3 dan Tabel 4.

Tabel 2. Keterangan Kode Pengambilan Sampling di Anak Sungai Citarum

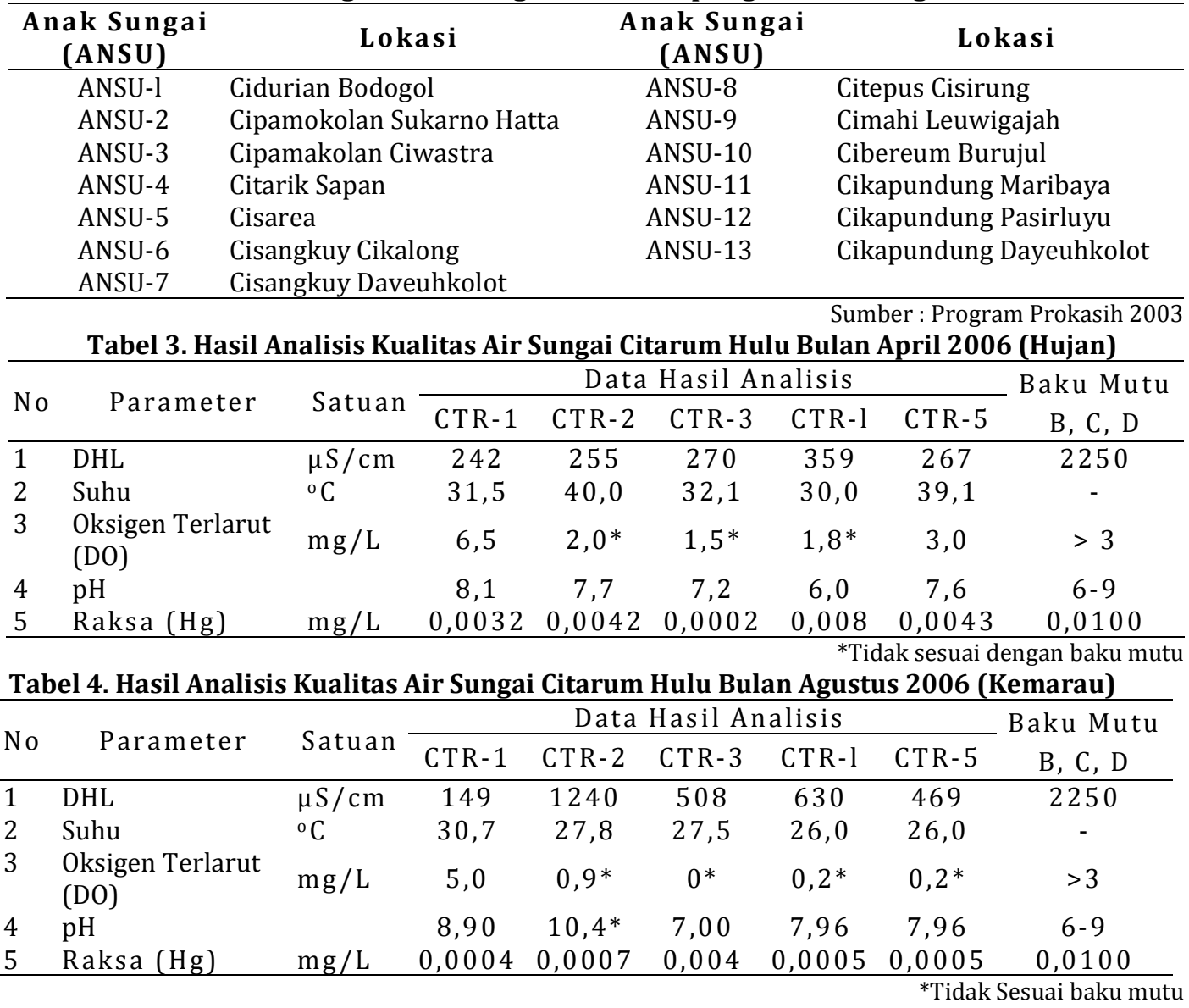


Pada musim hujan walaupun terjadi pengenceran tiga titik di Sungai Citarum, nilai DO masih berada di bawah baku mutu yang ditetapkan. Tiga titik tersebut mempunyai suhu yang cukup tinggi antara $39-40{ }^{\circ} \mathrm{C}$, sedangkan nilai $\mathrm{pH}$ masih berada dalam rentang baku mutu, begitu pula kandungan logam raksa masih berada di bawah baku mutu.
Berdasarkan hasil analisis pada musim kemarau empat dari lima titik pengamatan, kandungan DO berada di bawah baku mutu, bahkan di dua titik pengamatan mencapai nilai nol, berarti kondisi septik telah terjadi di bagian sungai tersebut. Nilai $\mathrm{pH}$ cukup tinggi bahkan ada satu bagian sungai yang melebihi baku mutu. Konsentrasi raksa dan oksigen terlarut pada bulan April dan Agustus dapat dilihat pada Gambar 2 dan 3.

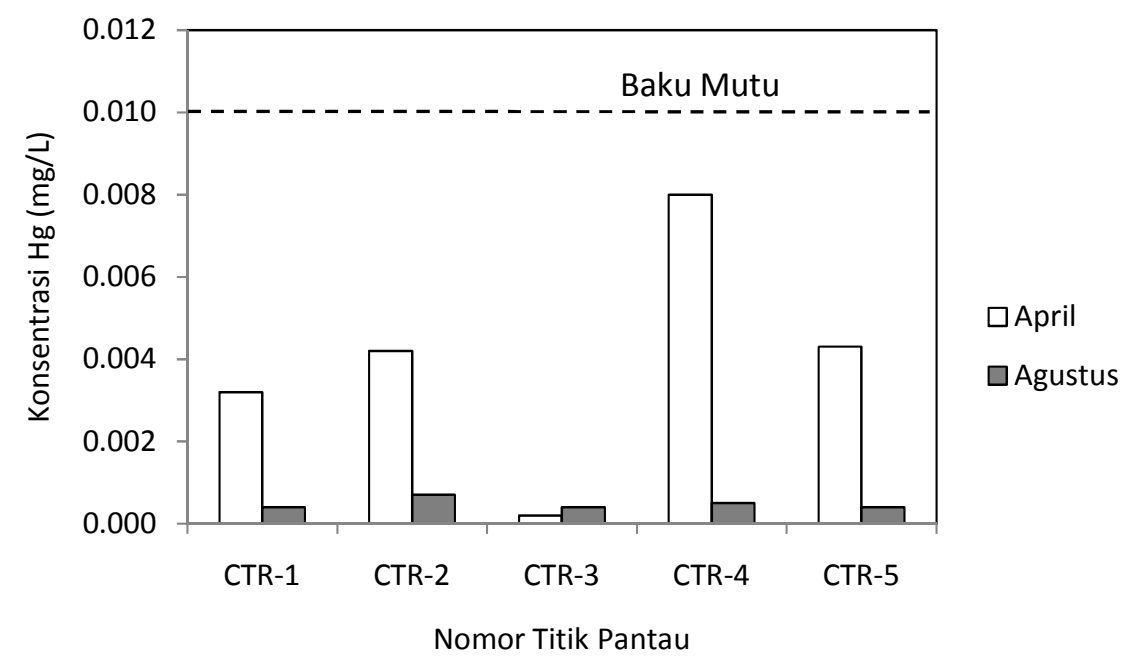

Gambar 2. Konsentrasi logam berat Raksa di Sungai Citarum Hulu pada bulan April dan Agustus

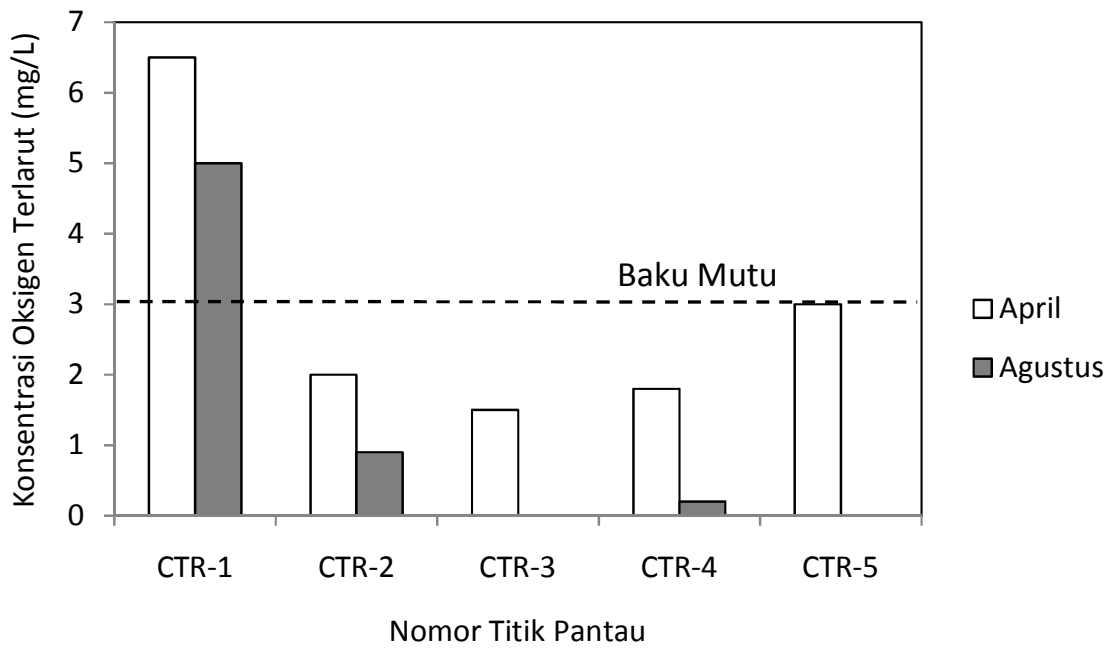

Gambar 3. Oksigen terlarut (DO) di Sungai Citarum Hulu pada bulan April dan Agustus 
Tabel 5. Hasil Analisis Kualitas Air Anak Sungai Citarum Hulu Bulan April 2006 (Hujan)

\begin{tabular}{|c|c|c|c|c|c|c|c|c|c|}
\hline \multirow{2}{*}{ No } & \multirow{2}{*}{ Parameter } & \multirow{2}{*}{ Satuan } & \multicolumn{7}{|c|}{ Data Hasil Analisis Anak Sungai (ANSU) } \\
\hline & & & 1 & 2 & 3 & 4 & 5 & 6 & 7 \\
\hline 1 & DHL & $\mu \mathrm{S} / \mathrm{cm}$ & 285 & 222 & 257 & 261 & 249 & 223 & 248 \\
\hline 2 & Suhu & ${ }^{\circ} \mathrm{C}$ & 30,7 & 28 & 29,2 & 29,3 & 32,0 & 34,0 & 39,3 \\
\hline 3 & Oksigen Terlarut & $\mathrm{mg} / \mathrm{L}$ & 4,0 & 4,0 & 4,5 & 5,3 & 6,0 & 4,5 & 4,0 \\
\hline 4 & $\mathrm{pH}$ & - & 8,4 & 8,6 & 7,6 & 7,7 & 7,9 & 8,1 & 7,4 \\
\hline 5 & Raksa (Hg) & $\mathrm{mg} / \mathrm{L}$ & 0,0002 & 0,0002 & 0,0002 & 0,0032 & 0,0033 & 0,0002 & 0,0002 \\
\hline \multirow{2}{*}{ No } & \multirow{2}{*}{ Parameter } & \multirow{2}{*}{ Satuan } & \multicolumn{7}{|c|}{ Data Hasil Analisis Anak Sungai (ANSU) } \\
\hline & & & 8 & 9 & 10 & 11 & 12 & 13 & $\mathrm{BM}$ \\
\hline 1 & DHL & $\mu \mathrm{S} / \mathrm{cm}$ & 623 & 1.283 & 478 & 86 & 211 & 275 & 2.250 \\
\hline 2 & Suhu & ${ }^{\circ} \mathrm{C}$ & 32,1 & 33,6 & 33,0 & 26,0 & 32,0 & 33,5 & - \\
\hline 3 & Oksigen Terlarut & $\mathrm{mg} / \mathrm{L}$ & $0,3^{*}$ & $0,5^{*}$ & 4,5 & 6,0 & 5,0 & 4,0 & $>3$ \\
\hline 4 & $\mathrm{pH}$ & - & 7,6 & 9,3 & 7,7 & 8,07 & 7,5 & 7,4 & $6-9$ \\
\hline 5 & Raksa (Hg) & $\mathrm{mg} / \mathrm{L}$ & $0,0228^{*}$ & 0,0183 & 0,0036 & 0,0027 & 0,0002 & 0,0041 & 0,0100 \\
\hline
\end{tabular}

*tidak sesuai baku mutu

Hasil analisis logam berat Raksa di anak Sungai Citarum Hulu pada pengukuran bulan April yang mewakili musin hujan menununjukkan bahwa terdapat dua titik yang melebihi baku mutu logam berat Raksa yaitu anak sungai Citepus Cisirung dengan kandungan 0,0228 mg/L dan Sungai Cimahi Leuwigajah 0,0183 mg/L. Kandungan logam berat yang tinggi disebabkan karena kedua anak sungai tersebut berada di kawasan industri Cisirung dan Cimahi, diduga kandungan logam berat raksa berasal dan industri yang berada di dua kawasan itu. Data hasil pengukuran selengkapnya dapat dilihat pada Tabel 5.
Berdasarkan hasil analisis bulan Agustus dan November mewakili musim kemarau di setiap titik pantau kandungan Raksa teridentifikasi tetapi masih di bawah baku mutu. Harus dievaluasi juga karakteristik logam berat dalam air bahwa ion logam tersebar kedalam air dan bergerak identik dengan gerakan air itu sendiri pada kondisi asam. Dalam bentuk suspended ion logam tersuspensi dalam air sebagai metal hidroksida pada kondisi basa ( $\mathrm{pH} \mathrm{8-11)} \mathrm{atau}$ mengendap di dasar perairan sesuai dengan pengaruh gaya gesek, gaya apung dan gaya gravitasi. Selain nilai $\mathrm{pH}$, parameter lain yang mempengaruhi keberadaan logam berat dalam air adalah nilai oksigen terlarut (DO) (Goldberg, 1983).

Tabel 6. Hasil Analisis Kualitas Air Anak Sungai Citarum Hulu pada Bulan Agustus 2006 (Kemarau)

\begin{tabular}{|c|c|c|c|c|c|c|c|c|c|}
\hline \multirow{2}{*}{ No } & \multirow{2}{*}{ Parameter } & \multirow{2}{*}{ Satuan } & \multicolumn{7}{|c|}{ Data Hasil Analisis Anak Sungai (ANSU) } \\
\hline & & & 1 & 2 & 3 & 4 & 5 & 6 & 7 \\
\hline 1 & DHL & $\mu \mathrm{S} / \mathrm{cm}$ & 660 & 942 & 883 & 823 & 214 & 105 & 648 \\
\hline 2 & Suhu & ${ }^{\circ} \mathrm{C}$ & 24,5 & 23,6 & 23,6 & 29,2 & 25,1 & 34,2 & 32,5 \\
\hline 3 & Oksigen terlarut & $\mathrm{mg} / \mathrm{L}$ & $1,5^{*}$ & $1,9 *$ & $0,5^{*}$ & 3,2 & 3,0 & 5,0 & $0 *$ \\
\hline 4 & $\mathrm{pH}$ & - & 8,02 & 7,93 & 7,81 & $9,26^{*}$ & 7,60 & 7,68 & 7,56 \\
\hline 5 & Raksa (Hg) & $\mathrm{mg} / \mathrm{L}$ & 0,0002 & 0,0002 & 0,0002 & 0,0004 & 0,0003 & 0,0005 & 0,00100 \\
\hline \multirow{2}{*}{ No } & \multirow{2}{*}{ Parameter } & Sot & \multicolumn{7}{|c|}{ Data Hasil Analisis Anak Sungai (ANSU) } \\
\hline & & $\mathrm{S}$ & 8 & 9 & 10 & 11 & 12 & 13 & $\mathrm{BM}$ \\
\hline 1 & DHL & $\mu \mathrm{S} / \mathrm{cm}$ & $3.150 *$ & 1970 & 555 & 156 & 261 & 366 & 2.250 \\
\hline 2 & Suhu & ${ }^{\circ} \mathrm{C}$ & 30,1 & 25,1 & 25,0 & 20,1 & 25,0 & 26,2 & - \\
\hline 3 & Oksigen Terlarut & $\mathrm{mg} / \mathrm{L}$ & $0,6^{*}$ & $0^{*}$ & 3,0 & 6,0 & $1,5^{*}$ & $0,3^{*}$ & $>3$ \\
\hline 4 & $\mathrm{pH}$ & - & $12,08^{*}$ & 8,05 & 7,80 & 8,33 & 7,45 & 7,45 & $6-9$ \\
\hline 5 & Raksa (Hg) & $\mathrm{mg} / \mathrm{L}$ & 0,0013 & 0,0014 & 0,0004 & 0,0003 & 0,0028 & 0,0005 & 0,0100 \\
\hline
\end{tabular}


Tabel 7. Hasil Analisis Kualitas Air Anak Sungai Citarum Hulu di bulan November 2006 (Kemarau)

\begin{tabular}{|c|c|c|c|c|c|c|c|c|c|}
\hline \multirow{2}{*}{ No. } & \multirow{2}{*}{ Parameter } & \multirow{2}{*}{ Satuan } & \multicolumn{7}{|c|}{ Data Hasil Analisis Anak Sungai (ANSU) } \\
\hline & & & 1 & 2 & 3 & 4 & 5 & 6 & 7 \\
\hline 1 & DHL & $\mu \mathrm{S} / \mathrm{cm}$ & 459 & 745 & 780 & & 181 & 113 & 603 \\
\hline 2 & Suhu & ${ }^{\circ} \mathrm{C}$ & 24,3 & 24,8 & 25,4 & & 24,7 & 23,7 & 24,5 \\
\hline 3 & Oksigen Terlarut & $\mathrm{mg} / \mathrm{L}$ & $1,3^{*}$ & $0,5^{*}$ & $2,5^{*}$ & & 4,5 & 6,0 & $1,0^{*}$ \\
\hline 4 & $\mathrm{pH}$ & - & 6,5 & 6,6 & 6,7 & & 6,6 & 6,7 & 6,4 \\
\hline 5 & Raksa (Hg) & $\mathrm{mg} / \mathrm{L}$ & 0,0002 & 0,0002 & 0,0002 & & 0,0002 & 0,0002 & 0,0008 \\
\hline \multirow{2}{*}{ No } & \multirow{2}{*}{ Parameter } & \multirow{2}{*}{ Satuan } & \multicolumn{7}{|c|}{ Data Hasil Analisis Anak Sungai (ANSU) } \\
\hline & & & 8 & 9 & 10 & 11 & 12 & 13 & $\mathrm{BM}$ \\
\hline 1 & DHL & $\mu \mathrm{S} / \mathrm{cm}$ & 418 & 2.320 & 693 & 101 & 267 & 384 & 2.250 \\
\hline 2 & Suhu & ${ }^{\circ} \mathrm{C}$ & 25,0 & 26,0 & 27,5 & 20,5 & 25,0 & 26,0 & - \\
\hline 3 & Oksigen Terlarut & $\mathrm{mg} / \mathrm{L}$ & 3,0 & $2,0^{*}$ & $0,5^{*}$ & 4,0 & $2,0 *$ & $0,6^{*}$ & $>3$ \\
\hline 4 & $\mathrm{pH}$ & - & 6,6 & 7,7 & $9,1^{*}$ & 8,5 & 6,2 & 7,5 & $6-9$ \\
\hline 5 & Raksa (Hg) & $\mathrm{mg} / \mathrm{L}$ & 0,001 & 0,0002 & 0,0009 & 0,0002 & 0,0022 & 0,0002 & 0,01 \\
\hline
\end{tabular}

Berdasarkan hasil analisis pada bulan Agustus 2006 nilai oksigen terlarut (DO) di CTR-2 adalah 0,9 mg/L dengan $\mathrm{pH}$ 10,4, CTR-3 adalah $0 \mathrm{mg} / \mathrm{L}, \mathrm{CTR}-4$ adalah $0,2 \mathrm{mg} / \mathrm{L}$, dan CTR $50 \mathrm{mg} / \mathrm{L}$. Pada sebagian titik pengamatan di anak sungai menunjukkan bahwa nilai DO yang sangat kecil bahkan pada beberapa titik mencapai nilai DO nol. Nilai oksigen terlarut nol menunjukkan kondisi air yang tidak mengandung oksigen (anaerob septik). Pada kondisi nilai oksigen terlarut rendah dan $\mathrm{pH}$ basa sifat logam berat berada dalam kondisi mengendap sehingga konsentrasi logam berat. Raksa yang kecil di air diduga terjadi pengendapan logam tersebut karena kondisi air yang aerob. Hal yang sama terjadi juga pada pengukuran di anak sungai di beberapa titik yang mempunyai nilai oksigen terlarut rendah dan pH basa. Diasumsikan kandungan Raksa yang kecil di dalam air karena terjadi pengendapan logam berat tersebut sehingga terakumulasi di sedimen sungai atau dalam tubuh organisme (Goldberg, 1983).

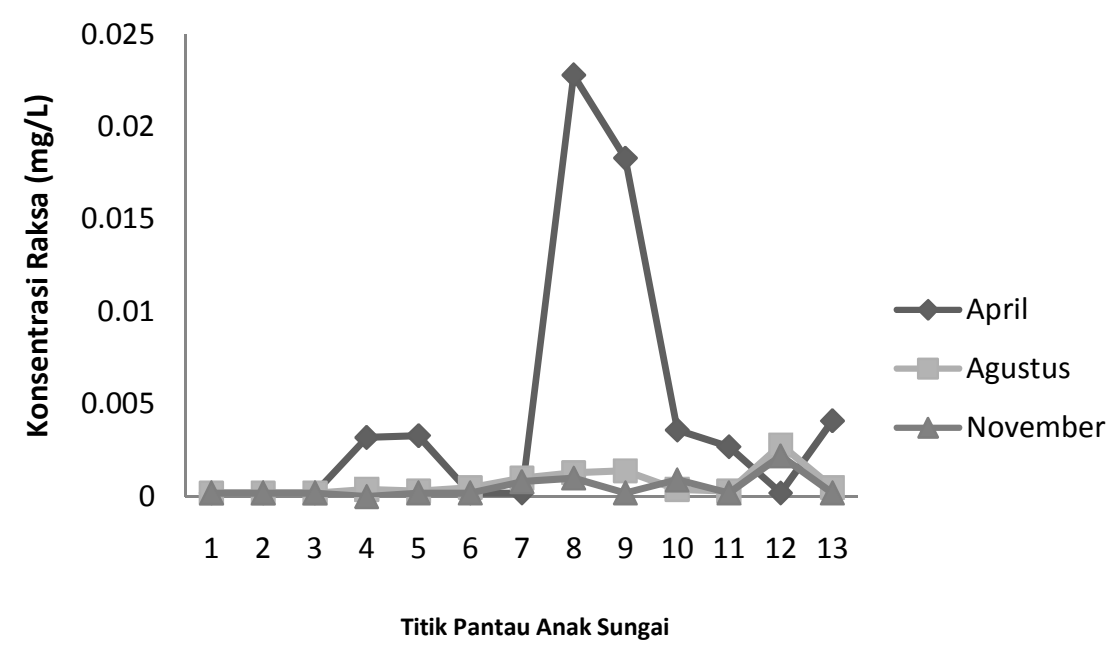

Gambar 4. Konsentrasi logam berat Raksa di anak Sungai Citarum Hulu pada bulan April, Agustus, dan November 
Akumulasi logam berat dapat juga terjadi dalam tubuh organism. Masuknya logam berat ke dalam tubuh organisme hidup dapat melalui tiga cara yaitu difusi melalui permukaan tubuh, insang dan rantai makanan, sedangkan cara keluar logam berat dari tubuh organisme dengan melalui dua cara yaitu ekskresi melalui dalam perut dan urine. Sebagian besar masuknya logam berat ke dalam tubuh organisme adalah melalui rantai makanan, sedikit saja yang diambil langsung dari air melalui proses adsorpsi. Pada rantai makanan fitoplankton yang merupakan awal dari rantai makanan akan dimakan oleh zooplankton, zooplankton akan dimakan oleh ikan-ikan kecil, ikan-ikan kecil akan dimakan oleh ikan-ikan besar, demikian seterusnya. Umumnya kandungan logam berat tertinggi dalam rantai makanan ditemukan pada invertebrata terbesar (Goldberg, 1983).

Dengan teridentifikasinya logam berat Raksa di air, maka organism yang ada di perairan tersebut terancam, karena dampak logam berat Raksa terhadap kesehatan manusia sangat berbahaya yaitu dapat menyerang sistem syaraf dan organ lainnya sehingga harus dilakukan upaya penanggulangan pencemaran di sungai dan anak Sungai Citarum Hulu supaya dampak yang merugikan tidak terjadi.

\section{Kesimpulan}

Dari penelitian ini dapat disimpulkan beberapa hal yaitu:

1. Kandungan logam berat Raksa di 5 titik pengamatan di Sungai Citarum Hulu pada pengamatan bulan April dan Agustus 2006 masih di bawah baku mutu yang ditetapkan.
2. Kandungan logam berat Raksa melewati baku mutu di anak sungai Citepus Cisirung dengan kandungan 0,0228 mg/L dan Sungai Cimahi Leuwigajah 0,0183 mg/L.

3. Kedua anak sungai tersebut di atas berada di kawasan industri Cisirung dan Cimahi, dan diduga logam berat berasal dari aktivitas industri di ke dua kawasan tersebut.

Perlu dilakukan penelitian untuk melihat kandungan logam berat Raksa di sedimen Sungai Citarum Hulu Hulu terutama untuk titik pemantauan yang mempunyai nilai $\mathrm{pH}$ basa dan Oksigen terlarut (DO) rendah. Selain itu perlu pula dilakukan pengendalian pencemaran logam berat Raksa untuk menghindari dampak yang akan merugikan kesehatan manusia.

\section{Daftar Pustaka}

Republika, 280 ton limbah cemari Sungai Citarum Hulu, http://www.republika.co.id, akses 28 juli 2002.

Departemen Pekerjaan Umum, Kumpulan SNI Bidang Pekerjaan Umum Mengenai Kualitas Air, Yayasan Badan Penerbit Pekerjaan Umum, Jakarta, 1991.

Goldberg, E. D.,Metal Polution in The Aquatic Environment, Springer Verlag, Berlin, 1983.

Pemerintah Propinsi Jawa Barat, Program Kali Bersih (Prokasih), Badan Pengendalian Lingkungan Hidup Daerah, 2003.

Pemerintah Propinsi Jawa Barat, Pengelolaan DAS di Jawa Barat, Kasus DAS Citarum Hulu, Badan Pengendalian Lingkungan Hidup Daerah, 2003. 